\title{
The Cooperatives as an Alternative Partners for Social and Economic Development: Its Perceived Attainment to the Sustainable Development Goals(SDG)
}

\author{
Loneza Gas-ib - Carbonel, PhD
}

\begin{abstract}
Associate Profess or-College of Liberal Arts, Kalinga State University, Tabuk City,Kalinga, Philippines
\end{abstract}
\begin{abstract}
This study focused on the assessment of the socioeconomic status and analysis of the financial and social services of the four(4) selected cooperatives in Tabuk City, Kalinga, Philippines. The descriptive and empirical method was used in the study. The extracted data included the following indicators of the Cooperatives' financial reports such as the following: Assets, Deposits, and Loans, Net Surplus, Dividends and Patronage refunds.It also conducted a survey from the selected 300 cooperative members on the level of participation of the Cooperatives to the attainment of the Sustainable Development Goals (SDG) of the Philippines.The objectives of the study are summarized as follows : to describe the profile of the cooperatives in terms of its assets, number of members, and age;to determine the members' economic participation according to their average assets, share capital, deposits, and gross surplus,to determine the members' economic benefits of the four cooperatives ;o identify the percentage of participation in social and financial obligations of the four cooperatives, and to find out the percentage of contribution the cooperatives have contributed to the sustainable development goals (SDG) as partners for social and economic development of the country.
\end{abstract}

This study found that: the Cooperatives have generated a total of four billion worth of assets and a total members of 16,437,the cooperative greatly contributes to its assets, there is a significant difference in the members' economic participation on the cooperatives' services. Moreover, the cooperatives extended funds for the needs of communities, the cooperative as an economic institution had helped a lot as partners for development and provide quality education as well as in sustaining decent work and economic growth, responsible consumption and production, and peace, justice and strong institution. Finally, the percent contribution of the cooperative in attaining the sustainable development goals of the government is at most 49 percent.

Keywords- Cooperatives, Socioeconomic Status, Deposits, Economic Benefits, Social Contribution.

\section{INTRODUCTION}

Long years ago, people have been facing problems of economic due to poverty, exclusion, and inequality all over the world. For this reason, they proposed a new way of addressing their needs like putting up cooperatives. The concept evolved between the practical and the ideal, inspired by the values of equality, democracy, liberty, fairness, solidarity, and empowerment. This organizational change now became a challenge to our concepts of the economy and business management.

The study of Dogarawa Ahmad Bello (2005), he quoted the definition of cooperative based on "The International Cooperative Alliance (ICA) in its Statement on the Cooperate Identity, in 1995, defines a cooperative as "an autonomous association of persons united voluntarily to meet their common economic, social, and cultural needs and aspirations through a jointly-owned and democratically controlled enterprise." It is a business voluntarily owned and controlled by its member patrons and operated for them and by them on a nonprofit or cost basis (UWCC, 2002).

The Copenhagen Social Summit, 1995 defined Social Development in terms of three basic criteria: Poverty Eradication, Employment Generation, and Social Harmony According to Amartya Sen, 1995 "Social Development is equality of social opportunities." According to M.S Gore, the concept of social development is inclusive of economic development but it emphasizes the development of the society in a totality that is, in its economic, political, social and cultural aspects.

In the Philippines, particularly in the Cordillera region,based on the CDA reports, there are forty-one (41) 
cooperatives that are operational since it has been marked that the principle behind the cooperative is an effective means to improving the socioeconomic well-being of the people in the community. On December 2015, the Cooperative Development Authority(CDA) of the Philippines reported 9,826 cooperatives complied with the reportorial requirements of the $\mathrm{CDA}$, including the submission of audited financial statements Their combine numbers constitute $68 \%$ of the total number of reporting cooperatives. The total volume of business generated by all cooperatives, as of December 2015, was PhP322, 697.5 Million and engaging direct employment of 463,789 persons.

The functions of cooperative help the government economic system in solving such poverty problems in the country. Although we knew that the government is providing poverty alleviation programs, this cannot still meet the people's need for financial assistance.

Cooperative organizations are a voluntary organizations initiated by the people, as it is a "self help". "People should seek it because they see a use for it", shares Dr. Castillo, which is why as much as they can, they educate people on the benefits of cooperative organizations, more so, if they are able to make it grow. "People should be taught of the world and its businesses,(www.cda.gov.ph/.).

From the study of Deriada*(2005), she wrote that : As a Business Enterprise Generally, cooperative enterprises are considered as an attractive model of business organization due to following reasons: a) they are run as democratic enterprises where members have the control over their own business and operate it to meet their common needs, thus enabling them to be socially and economically self reliant citizens; b) by pooling members' financial resources, the cooperative canprovide a way to raise capital; c) cooperatives provide members with a guaranteed market for their produce and lastly, d) cooperatives contribute to rural development by affecting the lives of their members through increase in employment and improvement in financial position and social conditions (Quintana, 1996).

Based on membership, the CDA reported as of December 2002 that there were a total of 2.8 million and 0.8 million regular and associate members in primary cooperatives respectively. Their contribution to the national output has been continuously increasing providing a total of 65,196 and 18,796 jobs in fulltime and part time employment respectively. It has also generated a total of PhP13.9 billion in net surplus and has accumulated a total of PhP76.1 billion worth of assets with paid -up capital of around PhP 22.2 billion.
In our economy today, salaries and wages are no longer enough as sources of financial supports for the family budget. But, with the establishment and operation of cooperatives in the communities and sectors of the economy, personal income limitations can be augmented in terms of borrowings from the cooperatives, which has a lower interest rates and returns on investment for every member borrower. The cooperative way of financing and investing is much affordable among the members. Therefore, it is must engage in cooperative investment in order to be prepared for any urgent financial needs.

The best practices of cooperatives are beneficial to the members and to other financial institutions to note. Thus, this study was conducted to disseminate the significant contributions of cooperatives as partners of government and private industries in providing sources of funds and opportunities for wiser investment and elevate the economic and social development of a country like the Philippines and other countries in the world.

\section{OBJECTIVES OF THE STUDY}

This study purposely aimed to assess the general status of the selected cooperatives in Tabuk City,Kalinga in order to seek answers to the following objectives:

1.To determine the socioeconomic profile of the four cooperatives as to rank in size, number of members, age, savings, share capital,average loan, average assets, patronage refund, and net surplus, in the past five years of operation from 2013to 2018

1.1.Is there a significant relationship of the Cooperatives' age to the average amount of assets?

2.To determine the members' economic participation of the four cooperatives according to their average assets, share capital, deposits, and gross surplus.

2.1 Has there been is a significant difference of the members' economic participation among the four cooperatives?

3.To determine the average members' economic benefits from the four cooperatives' performances from 2013to 2018.

3.1 Is there a significant difference of the members 'economic benefits when grouped according to the four cooperatives' allocation and distribution?

4.To determine percentage of participation of the cooperatives in giving financial supports to the 
beneficiary, NGOs, and the poor sectors of the community.

5. To determine the percent of contribution or participation of the cooperatives in attaining the 9-points sustainable development goals of the government.

\section{METHODOLOGY}

This study used the descriptive method through documentary analysis of the annual reports of the selected cooperatives in Tabuk City, Kalinga, Philippines. The researcher conducted the study to explore the financial and social services of the Cooperatives and investigate if there are significant differences in the financial performance of the cooperatives. It also evaluated the economic participation of the members, the economic benefits derived by the members. Likewise, the social and economic contributions of the cooperatives were also analysed and discussed. The extracted data included the following indicators of the Cooperatives' financial reports such as the following: Assets, Deposits, and Loans, Net Surplus, Dividends and Patronage refunds.It also conducted a survey from the selected 300 cooperative members on the level of participation of the Cooperatives to the attainment of the Sustainable Development Goals (SDG) of the Philippines.

\section{LOCALE OF THE STUDY}

The study was conducted among the four of the cooperatives that are located at Tabuk City, Kalinga, Philippines.

\section{RESPONDENTS}

The subjects of this study composed the four cooperative entities, located at Dagupan and Bulanao, Tabuk City, Kalinga.These cooperatives that are located at Tabuk City, Kalinga,Philippines, they are: Tabuk Multipurpose Cooperative (TAMPCO), the BIBAK Multipurpose Cooperative (BIBAKMPC), and Tabuk Farmers Multipurpose Cooperative (TAFAMULCO) and St.Thomas Parish Church Credit Cooperative(STPCC). The four cooperatives were assessed on their profiles as institutions. And, the three hundred respondents were assessed about their the participation and contribution of the cooperatives in the economic and social development development goals.

Table 1 The Profile of the Four Cooperatives based on the Fionancial and Social Services.

\begin{tabular}{|l|l|}
\hline Cooperatives & Services \\
\hline & Deposits \\
Tabuk Multipurpose Cooperative & Credit \\
(TAMPCO) & Pi Water \\
& TITC- training center \\
& TFC- Funeral Center \\
& TGAS-Gasoline station \\
\hline \multirow{2}{*}{ Tabuk Farners' Multipurpose Cooperative } & Deposits \\
(TAFAMULCO) & Credit \\
& TSP \\
BIBAK Multipurpose Cooperative & Agriculture \\
\hline & Deposits \\
St.Thomas Parish Church Credit Cooperative & Credit \\
& Carenderia \& Canteen \\
\hline
\end{tabular}

The Tabuk Multipurpose Cooperative (TAMPCO) as the oldest established cooperative in Tabuk city offers more businesses than the others. The Tabuk Farmers Multipurpose Cooperative is the second oldest established among them, followed by the BIBAK Multipurpose Cooperative, and the youngest is the St. Thomas Parish Church Credit Cooperative (STPCC).

As to size, it is seen that TAMPCO is ranked 1 and it is a billionaire. While the rest are classified as millionaires. As to membership, the TAMPCO has the highest number, followed by St. Thomas Parish Credit Cooperative, Tabuk Farmers' Multipurpose Cooperative (TAFAMULCO, and the BIBAK Multipurpose Cooperative (BIBAKMCO). As to assets: the TAMPCO rank First followed by the TAFAMULCO, BIBAKMCO, and STPCC.

\section{DATA GATHERING}


The data were gathered through the use document analysis and data mining from the annual reports of the selected cooperatives (subject of the study). The secondary data on the financial profiles of the cooperatives were used in this context study. The specific indicators which were considered as the focused of the study are : members 'economic participation ,the economic benefits that they derived from the participation in the cooperatives, and the socioeconomic contribution of the cooperatives towards the environment and communities of the Kalinga Province.

\section{DATA TREATMENT}

The data gathered and summarized by the use of statistical tables. The data were analysed and compared through the use of frequency, averaging, ranking, and percentage.

\section{STATISTICAL TREATMENT}

The treated data shall be processed using statistical formulas as follows: Mean, Rank, and percentage, Regression Correlation and Analysis of Variance. The comparative analysis was done through the use of analysis of variance.

\section{RESULTS AND DISCUSSIONS}

Table 2 the Profile of the Four Cooperatives as to Number of Members, Average Assets, and Age.

\begin{tabular}{|c|c|c|c|}
\hline Name of Cooperatives & $\begin{array}{l}\text { Number of Members } \\
\text { As of Dec. } 2018 \\
\text { And their rank }\end{array}$ & $\begin{array}{l}\text { Average Assets } \\
\text { (2015to 2018) } \\
\text { and their ranks }\end{array}$ & $\begin{array}{l}\text { Age of the } \\
\text { Cooperative } \\
\text { s }\end{array}$ \\
\hline $\begin{array}{ll}\text { Tabuk } & \text { Multipurpose } \\
\text { Cooperative } & \\
\text { (TAMPCO) } & \end{array}$ & $\begin{array}{l}13,937 \\
(1)\end{array}$ & $\begin{array}{l}\mathrm{P} 1,088,257,417.11 \\
\text { (1) }\end{array}$ & 45 years \\
\hline $\begin{array}{l}\text { Tabuk } \\
\text { Farmers'Mutipurpose } \\
\text { Cooperative } \\
\text { (TAFAMULCO) }\end{array}$ & $\begin{array}{l}667 \\
(3)\end{array}$ & $\begin{array}{l}291,667,135.29 \\
\text { (2) }\end{array}$ & 33 years \\
\hline $\begin{array}{lc}\text { BIBAK } & \text { Multipurpose } \\
\text { Cooperative(BIBAKMCO) }\end{array}$ & $\begin{array}{l}406 \\
(4)\end{array}$ & $\begin{array}{l}118,276,740.84 \\
\text { (3) }\end{array}$ & 30 years \\
\hline $\begin{array}{l}\text { St.Thomas Parish Credit } \\
\text { Cooperative(STPCC) }\end{array}$ & $\begin{array}{l}1,427 \\
(2)\end{array}$ & $\begin{array}{l}104,239,175.9 \\
(4)\end{array}$ & 14 years \\
\hline Total(Average) & 16,437 & & \\
\hline
\end{tabular}

The Tabuk Multipurpose Cooperative (TAMPCO) as the oldest established cooperative in Tabuk city offers more businesses than the others. The Tabuk Farmers Multipurpose Cooperative is the second oldest established among them, followed by the BIBAK Multipurpose Cooperative, and the youngest is the St.Thomas Parish Church Credit Cooperative (STPCC).

As to size, it is seen that TAMPCO is ranked 1 and it is a billionaire. While the rest are classified as millionaires. As to membership, the TAMPCO has the highest number, followed by St.Thomas Parish Credit Cooperative, Tabuk Farmers' Multipurpose Cooperative (TAFAMULCO, and the BIBAK Multipurpose Cooperative (BIBAKMCO). As to assets: the TAMPCO ranked 1 followed by the TAFAMULCO, BIBAKMCO, and STPCC. Finally, it also seen that the cooperatives have total members of 16,437 .

Table 3 the Correlation obetween Age and Assets of the Cooperatives, and between Number of members and Total Assets of the Cooperatives.

\begin{tabular}{|l|l|l|l|}
\hline Age and Total Assets & $\begin{array}{l}\text { Regression } \\
\text { Statistics }\end{array}$ & No. of Members and Totals Assets & Regression Statistics \\
\hline Multiple R & 0.82476 & Multiple R & .997 \\
\hline R Square & 0.680229 & R Square & 0.994694 \\
\hline Adjusted R Square & 0.520343 & Adjusted R Square & 0.992041 \\
\hline Standard Error & $3.23 \mathrm{E}+08$ & Standard Error & $4.78 \mathrm{E}+08$ \\
\hline
\end{tabular}

The relationship between years of age, of the cooperative and the amount of assets is positive and it is described as very high relationship. The table showed that as the cooperatives' years of age increases, the assets also 
increase. It reflected that the age contributes 0.68 or $68 \%$ in the economic growth of the cooperatives. It was also revealed that there is a significant relationship between the cooperatives' age and assets. There is a perfect correlation between the number of members the the total assets of the cooperatives.

Table 4 . Average Assets, Deposits, Share Capital, Loans, and Net Surplus (in Pesos) of the Four Cooperatives for the past four years of Operations ( 2014 to 2018)

\begin{tabular}{|l|c|c|c|c|c|c|}
\hline $\begin{array}{l}\text { Financial } \\
\text { Profile }\end{array}$ & $\begin{array}{l}\text { Tabuk } \\
\text { Multipurpose } \\
\text { Coop(TAMPC } \\
\text { O) }\end{array}$ & $\begin{array}{l}\text { Tabuk Farmers } \\
\text { Coop }\end{array}$ & $\begin{array}{l}\text { BIBAK } \\
\text { Mulptipurpos } \\
\text { e Coop }\end{array}$ & $\begin{array}{l}\text { St.Thomas } \\
\text { ParishCredit } \\
\text { Coop }\end{array}$ & Total & Rank \\
\hline Total Assets & $1,088,257,417$ & $291,667,135$ & $118,276,740$ & $104,239,175$ & $1,602,440,469$ & $\mathbf{1}$ \\
\hline $\begin{array}{l}\text { Time and } \\
\text { Savings }\end{array}$ & $609,904,399$ & $229,695,604$ & $25,427,779$ & $49,107,343$ & $914,135,125$ & $\mathbf{3}$ \\
\hline Share Capital & $372,890,464$ & $109,743,072$ & $20,249,333$ & $40,409,575$ & $543,292,445$ & $\mathbf{4}$ \\
\hline Dividends & $24,744,261$ & $6,522,085$ & $2,081,962$ & $10,457,206$ & $43,805,515$ & $\mathbf{5}$ \\
\hline $\begin{array}{l}\text { Total Loans } \\
\text { Receivables }\end{array}$ & $444,711,940$ & $167,795,765$ & $101,699,016$ & $74,717,208$ & $788,923,931$ & $\mathbf{2}$ \\
\hline Net Surplus & $47,884,525$ & $15,280,359$ & $3,018,354$ & $5,083,955$ & $71,267,194$ & $\mathbf{7}$ \\
\hline $\begin{array}{l}\text { Patronage } \\
\text { Refund for } \\
\text { Borrowers only }\end{array}$ & $12,234,837$ & $2,785,829$ & $2,582,517$ & $1,493,886$ & $19,097,070$ & $\mathbf{8}$ \\
\hline $\begin{array}{l}\text { Net Surplus } \\
\text { before provision }\end{array}$ & $47,756,660$ & $34,135,158$ & $4,023,449$ & $7,452,163$ & $93,367,432$ & $\mathbf{6}$ \\
\hline \\
Total
\end{tabular}

The table revealed that the total amount that the four cooperatives have generated and utilized for its services to their members and the community have reached four billion,seventy-six million,three hundred twenty-nine thousand and one hundred eighty five pesos ( $\mathrm{P}$ $4,076,329,185$ ) from 2013 to 2018. As to the cooperatives share in the total amount, the Tabuk multipurpose cooperatives(TAMPCO) has the greatest total which is $(65 \%)$ or $\mathrm{P} 2,648,384,506$, the second is the Tabuk Farmers Cooperative with a total amount of $\mathrm{P}$
$857,625,010$ or $21 \%$, the third is the St.Thomas Parish Credit Cooperative with a total amount of P 92,960,515 or $7.2 \%$, and the fourth is the BIBAK Mulptipurpose Coop with a total amount of P $277,359,152$ or $6.8 \%$.

The amount of money being generated by the operation of the cooperatives from the different services showed evidences of active participation in serving their members financial and economic demands and needs.

Table 7 Present the Summary of Averages on the Cooperatives Members Economic Participation

\begin{tabular}{|l|l|l|}
\hline Members' Economic Participation & Average amount in Pesos & Rank \\
\hline Share capital & $135,823,111$ & $\mathbf{2}$ \\
\hline Savings \& Time Deposit & $228,533,781$ & $\mathbf{1}$ \\
\hline Net surplus & $17,784,833$ & $\mathbf{3}$ \\
\hline
\end{tabular}

The data in the table also shown that along the members' economic participation, the amount of savings and time deposits of the cooperatives is ranked 1 , followed by the amount of share capital and the net surplus. This indicates that the operations of cooperatives have generally provided economic benefits to its members. As expected, that the members should gain mutual benefits in terms of the financial services such income from dividends and the provisions for loans. 
Table 8 Present Whether there is a Significant Difference on the Members' Economic Participation among the Four Cooperatives using ANOVA single factor.

\begin{tabular}{|l|l|l|l|l|l|l|}
\hline Source of Variation & SS & df & MS & F & P-value & F crit \\
\hline Between Groups & $5.45 \mathrm{E}+17$ & 3 & $1.82 \mathrm{E}+17$ & 3.909264 & 0.023908 & 3.098391 \\
\hline Within Groups & $9.29 \mathrm{E}+17$ & 7 & $4.64 \mathrm{E}+16$ & & & \\
\hline Total & $1.47 \mathrm{E}+18$ & 11 & & & & \\
\hline
\end{tabular}

Significant at .05

The test indicates that there is a significant difference in the Members' Economic Participation among the Four Cooperatives as revealed by the result of the F-ratio of 3.909 which is higher than the F-critical value of 3.098 at 0.05 ,level of significance. The differences lie between the amount of the members' economic contribution along the indicators such as amount of deposits and gross surplus. This gives an idea that the cooperatives should also guard the direction of their operations that the managers should look into the convenient techniques to convince more the members to sustain increases in their deposits and share capitals in their respective cooperatives.

Table 9 Present the Distribution of Members' Economic Benefits derived from the Operations of the Four Cooperatives

\begin{tabular}{|l|l|l|l|l|l|}
\hline $\begin{array}{l}\text { Members' } \\
\text { Economic Benefits } \\
2015 \text { to 2017) }\end{array}$ & $\begin{array}{l}\text { TAFAMULCO } \\
\text { (Average) } \\
\text { In Pesos }\end{array}$ & $\begin{array}{l}\text { BIBAK } \\
\text { (Average) } \\
\text { In Pesos }\end{array}$ & $\begin{array}{l}\text { STPCC } \\
\text { (Average) } \\
\text { In pesos }\end{array}$ & $\begin{array}{l}\text { TAMPCO } \\
\text { Average) } \\
\text { In pesos }\end{array}$ & Average \\
\hline Dividends & $6,522,085.20$ & $2,081,962.07$ & $10,457,206.70$ & $24,744,261.68$ & $10,951,378.91$ \\
\hline Patronage Refund & $2,785,829.44$ & $2,582,517.28$ & $1,493,886.53$ & $12,234,837.36$ & $4,774,267.65$ \\
\hline Total average & $9,307,914.64$ & $4,664,479.35$ & $11,951,093.23$ & $36,979,099.04$ & \\
\hline Rank & 3 & 4 & 2 & 1 & \\
\hline
\end{tabular}

On the Members' economic benefits derived from the four cooperatives, TAMPCO is the highest in terms of dividends and patronage refund allocation for the past three years in the amount of P36, 979,099.04. While St. Thomas Parish Church Credit Cooperative (STPCC) has allocated an average of P11, 951,093.23 for the members' dividends and patronage refund. The other cooperatives like TAFAMULLCO and BIBAKMCO also do allocate enough amounts for the members' financial benefits. Thus, the members are benefiting from their membership to the cooperative by saving while they have borrowed some money to use for their needs. In this manner, the establishment of a cooperative can help reduce poverty and restore people's economic security.

Table 10 Presents the Result of the ANOVA on the comparison of the Four Cooperatives along the Indicators of Members' Economic Benefits

\begin{tabular}{|l|l|l|l|l|l|l|}
\hline Source of Variation & SS & df & $M S$ & $F$ & $P$-value & F crit \\
\hline Between Groups & $3.20318 \mathrm{E}+14$ & 3 & $1.07 \mathrm{E}+14$ & 3.478866426 & 0.129869 & 6.591382 \\
\hline Within Groups & $1.22767 \mathrm{E}+14$ & 4 & $3.07 \mathrm{E}+13$ & & & \\
\hline Total & $4.43086 \mathrm{E}+14$ & 7 & & & & \\
\hline
\end{tabular}

Significant at .05

The result showed that there is no significant difference in the Cooperatives financial allocation for dividends and patronage refund to their members. This implies that the four cooperatives provide almost same amount of ratio for the allocation of the members' economic benefit like the dividends and patronage refund.

Table 11 Present the Different Socioeconomic Contribution (in Percent) Granted by the Cooperatives as perceived by the Beneficiaries

\begin{tabular}{|l|l|l|l|l|l|}
\hline $\begin{array}{l}\text { Cooperatives' Socioeconomic } \\
\text { Contribution }\end{array}$ & $\begin{array}{l}\text { TAMPCO } \\
\text { (Percent) }\end{array}$ & $\begin{array}{l}\text { TAFAMUL } \\
\text { CO } \\
\text { (Percent) }\end{array}$ & $\begin{array}{l}\text { BIBAKM } \\
\text { CO } \\
\text { (Percent) }\end{array}$ & $\begin{array}{l}\text { STPCC } \\
(\text { Percent })\end{array}$ & $\begin{array}{l}\text { Mean } \\
(\%)\end{array}$ \\
\hline Mortuary Aid & 100 & 100 & 100 & 100 & 100 \\
\hline
\end{tabular}




\begin{tabular}{|l|l|l|l|l|l|}
\hline Community Development Fund & 100 & 85 & 85 & 85 & 89 \\
\hline Education and Training Fund & 100 & 85 & 75 & 85 & 86 \\
\hline Health /Medical Fund & 85 & 90 & 90 & 85 & 88 \\
\hline Donations to typhoon victims & 100 & 95 & 85 & 85 & 91 \\
\hline $\begin{array}{l}\text { Funding for Church rehabilitation/ } \\
\text { improvement }\end{array}$ & 85 & 85 & 85 & 100 & 89 \\
\hline Funding of farmers' organization & 100 & 100 & 85 & 80 & 91 \\
\hline Giving of Tithe & 75 & 75 & - & 100 & 83 \\
\hline
\end{tabular}

The table reveals that the four cooperatives are participating in the social concerns through the use of allocated funds for aids that are provided by them to the different social concerns tike the community development fund, mortuary aid fund, education and training fund, health and medical aid fund..This is evidenced by the responses of the different beneficiaries of the cooperatives which shown as percent in the above table.

Table 12 .Cooperative's Contribution To The Attainment of Sustainable Development Goals (SDGs) as perceived by the Respondents $(n=300)$.

\begin{tabular}{|l|l|l|}
\hline Sustainable Development Goals & Number of Respondents & Percent \\
\hline 1.Zero hunger & 15 & 5 \\
\hline 2.Good Health and well being & 24 & 80 \\
\hline 3.Quality education & 200 & 67 \\
\hline 4.Gender equality & 58 & 19 \\
\hline 5.Decent work economic growth & 175 & 58 \\
\hline 6.Reduced Inequalities & 89 & 30 \\
\hline $\begin{array}{l}\text { 7.Responsible consumption and } \\
\text { production }\end{array}$ & 128 & 43 \\
\hline $\begin{array}{l}\text { 8.Peace, Justice and strong } \\
\text { institutions }\end{array}$ & 120 & 40 \\
\hline 9. Partnership for development & 285 & 95 \\
\hline Average \% & & $49 \%$ \\
\hline
\end{tabular}

The table reveals that the percent contribution of the cooperative in attaining the sustainable development goals of the government is $49 \%$. It can be seen in the table that most of respondents(of the 300 respondents) said that the cooperative as an economic institution had helped a lot as partners for development and provide quality education as well as in sustaining decent work and economic growth, responsible consumption and production, and peace, justice and strong institutions.

\section{v. CONCLUSIONS}

Based from the findings the following can be concluded:

1. Among the four cooperatives, the TAMPCO is ranked 1 with an average amount of $\mathrm{P} 435$, 234,235 in the members' economic participation indicators, followed by the TAFAMULCO, St. Thomas Parish Church Credit Cooperative(STPCC), and the BIBAKMCO.

2. The table showed that as the cooperatives' years of age increases, the assets also increase. It reflected that the age contributes 0.68 or $68 \%$ in the economic growth of the cooperatives. It was also revealed that there is a significant relationship between the cooperatives' age and assets. There is a perfect correlation between the number of members the the total assets of the cooperatives.

3. The relationship between years of age, of the cooperative and the amount of assets is positive and it is described as very high relationship

4. That there is a significant difference in the Members' Economic Participation among the Four Cooperatives.

5. On the Members' economic benefits derived from the four cooperatives, the TAMPCO is the highest in terms of dividends and patronage refund allocation for the past three years in the amount of P36, 979,099.04.

6. On the Cooperatives financial allocation for dividends and patronage refund to their members, the result showed that there is no significant difference This implies that the four cooperatives provide similar range or amount of ratio for the allocation of the members' 
economic benefit like the dividends and patronage refund.

7. the cooperatives as an economic institution had greatly contributed a lot as a partner for development in sustaining the SDG of the Philippines as evident by the different services which have provided quality education, decent work and economic growth, responsible consumption and production, and peace, justice and strong institutions. Finally, the percent contribution of the cooperative in attaining the sustainable development goals of the government is at most 49 percent

\section{REFERENCES}

[1] Beltran,Lea Manto(2017). Cooperatives as 'catalyst of change' Retrieved from www.cda.gov.ph/

[2] Capino ,Gonzalez,\&Pineda. Rizal's Life, Works and Writings: Their Impact on our National Identity. Philippine Copyright 1977,retrieved : books.google.com

[3] Craig, John G. In Juhani Laurinkari, ed. Cooperatives Today. A tribute to Dr. Laakkonen. Published in German and English. Geneva: International Cooperative Alliance: 93-118. retrieved :https://www.gsid.nagoya u.ac.jp/bpub/research/public/forum/28/04.pdf

[4] Deriada Forum of International Development Studies, March 2005 Assessment of Cooperative Movement in a Developing Country. The Philippine Experience. https://www.gsid.nagoy research/publication

[5] Dans Martin et al., 2012, p. 93). Mladenatz. (1933 German Rural Cooperatives, Friedrich-Wilhelm Raiffeisen . citeseerx.ist.psu.edu/viewdoc/download

[6] Dogarawa Ahmed Bello (2005). The Role of Cooperative Societies in Economic Development iasir.net/ AIJRHASSpapers/AIJRHASS14-112.pdf

[7] Eugenio T. Castillo, $\mathrm{PhD}$ and MERCEDES D. CASTILLO (2017). Cooperatives in the Socioeconomic Development of the Philippines Paper presented during the $10^{\text {th }}$ Asia Pacific Cooperative Ministers' Conference on April 18-21, 2017 in Hanoi, Vietnam. cda.gov.ph >.

[8] Rananavare, A.M. The Role of Cooperative Societies in the Economic Development of India retrieved

from https://digitalcommons.usu.edu/etd/2978/

[9] O’Sullivan, Arthur; Sheffrin, Steven M. (2003). Economic: Principles in Action. Upper Saddle River, New Jersey: Pearson Prentice Hall. p. 272.
ISBN 978-0-13-063085-8.

Retrieved: https://books.google.com > Business \& Economics

[10] Whitney, Edison (18610. Cooperative Credit Societies (Credit Unions) in America and in Foreign Countries: Bulletin of the United States Bureau of Labor Statistics, No. 314. Retrieved from_https://fraser.stlouisfed.org/title/3978 